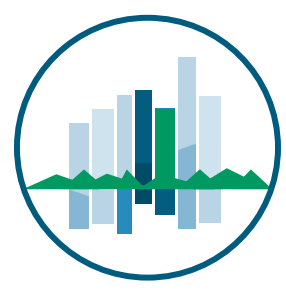

True Smart and Green City? 8th Conference of the International Forum on Urbanism
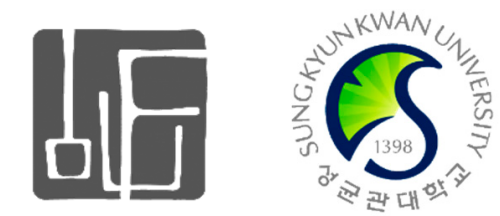

Conference Proceedings Paper

\title{
Actors' Role in Turning Constraints Into Opportunities: Disseminating Sustainable Urban Water Management Practices in Forest Municipality, Brussels, Belgium
}

\section{Catalina Codruta Dobre *, Marco Ranzato and Lusia Moretto}

Faculty of Architecture, Université Libre de Bruxelles, Place Flagey, 1050 Brussels, Belgium

* Author to whom correspondence should be addressed: Tel.: +32-486-730-989;

E-Mail: Catalina.Dobre@ulb.ac.be

\begin{abstract}
Since 2000, with the elaboration of the Water Framework Directive (WFD), a general agreement was achieved at the European level for implementing sustainable urban water management (SUWM) practices. However, there is criticism on the applicability of the WFD at the local level leading to disparities between administrative units of the same region or state (Andersson, Petersson, and Jarsjö 2012). Even so, research based on Australian cases revealed that regardless the regional or national legislation, discrepancies between administrative units have a local origin (M. Brown and Libeman 2004). This paper aims to present an interesting case of fit-for-purpose governance in Forest Municipality, Brussels Capital Region, Belgium, that is currently enabling the implementation of SUWM practices through a combination of top-down (the establishment of a municipal water department) and bottom-up (non-profit organizations, citizens' committees) management. Based on the investigation of the present water policies and on the mapping of the social-ecological systems, this paper evaluates the different governance structures and governance processes in relation to their outcomes in their transition towards SUWM practices.
\end{abstract}

Keywords: sustainable urban water management; fit-for-purpose governance framework; Forest Municipality, Belgium. 


\section{Introduction}

Currently, sustainable urban water management practices (SUWM) focus mostly on stormwater management and are referred to in the specific literature in North America, as Low Impact Development [1], in UK, as Sustainable Urban Drainage System [2], and in the French-speaking community, as Alternative Measure to Surface run-off [3]. Recently, the use of the term WSUD grew in importance and moved from Australia also to UK, the Netherlands or Germany due to its wider applicability to grey or black water $[4,5]$. The development of this wide range of terminology shows the different concerns and forms of sustainable practices [6].

Research based on the practice of SUWM shows that there are several reasons behind their low dissemination: a lack of correlation between their construction and maintenance $[7,8]$, the uncertainty regarding who should pay for their implementation and maintenance [9], a reduced level of community acceptance [7,10], the unclear role of the property owner [8] and, the unclear connection with the concept of 'sustainability' [8]. At the level of governance mechanisms, research shows that there is a lack of benchmarking at policy level [11] and a lack of understanding on how to enable the change from conventional to SUWM practices [12].

The introduction of water policies at the European level, starting with the year 2000, such as the Water Framework Directive (WFD), put pressure on the Member States to implement SUWM. However, at the level of local councils, the implementation of WFD proved to be difficult [13]. Research based on Australian cases showed that disparities between how each local council applies water polies appear due several local causes: the capacity for local governance systems to accept innovative ideas, to have a leading actor in SUWM practices and, to enhance interdisciplinary approaches [14]. The adaptive governance, aims to create similar conditions by combining top-down and bottom-up initiatives with a strong emergence of "bridging" actors [15]. However, there is lies in its application [16].

The fit-for-purpose framework is meant to evaluate the way in which the proposed measures are fit for the objectives and deliver the expected results [12]. Researchers developed this framework to help understand the difficulties of administrations to adapt to uncertainties and complexity, such as the transition to SUWM practices [12]. The framework was tested on cities from Australia and the Netherlands and was usually used to compare case studies in three steps: the purpose of the governance mechanism, the mapping of the context and the evaluation of proposed measures.

New knowledge is brought to the concept of adaptive governance by the fit-for-purpose governance framework in applicability. While the adaptive governance focuses on the transition and adaptation to changes, fit-for-purpose framework helps in understanding the efficiency of a given mechanism based on its objectives [16]. The flexibility of the framework allows its application in different contexts in the transition towards SUWM practices.

One of the 19 municipalities in Brussels Capital Region (BCR), Forest is an interesting case of implementing SUWM practices and one of the most advanced in this direction, standing apart from the whole region. This paper aims to investigate the governance mechanisms put in place in Forest, which allowed a faster dissemination of SUWM practices. The fit-for-purpose governance framework is used to analyze and organize the information related to the case study and to draw attention on its applicability at the local scale. Based on the Forest case study, the paper highlights the complex relationship structure, which arose among the different stakeholders. The results draw attention on the development of Forest 
governance structure from a top-down - bottom-up institutional linkage to relationships of development, empowerment and co-management between the main actors. This transition is enabled by the development of two organizations, Forest Water Department and EGEB association, as bridging organizations with the main purpose of enabling a transition towards SUWM practices.

\section{Methods}

The fit-for-purpose framework is an interesting tool for enabling a better understanding of the development towards SUWM practices in Forest. Based on the proposed framework [17], the analysis of the case of Forest will be carried in three steps: the purpose of the governance mechanisms, the mapping of the context they activate and the evaluation of the outcomes. Each step is meant to enable a better understanding of how governance mechanisms work, who enables or implements them, the drivers behind their implementation and if they are really effective in achieving the objectives.

Figure 1. (a) Adaptation of the fit-for-purpose framework to the Forest case study.

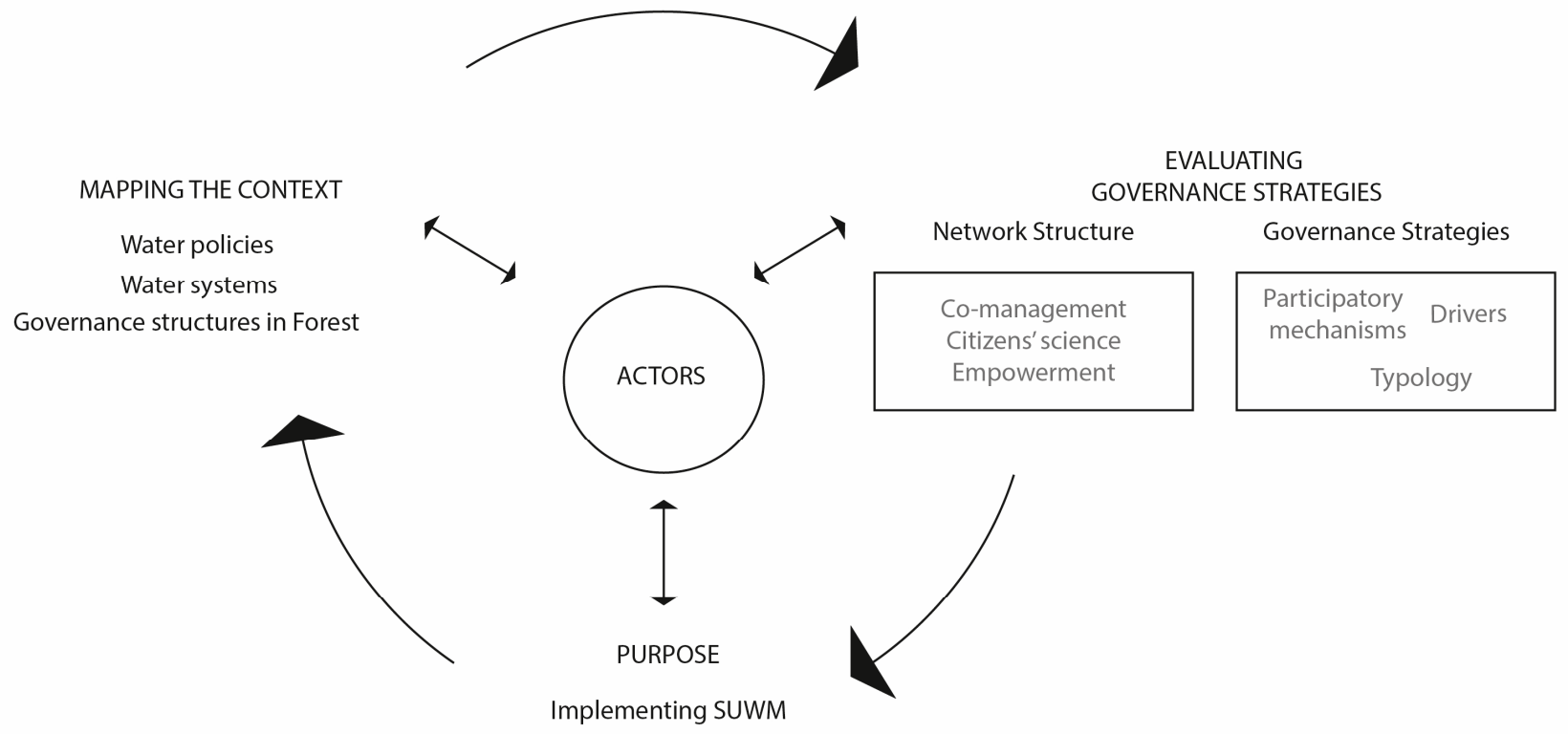

Firstly, in the European context, the pressure of enabling the transition to a sustainable water management is not as visible as in the Australian case studies, where long periods of drought and constant loss of water resources forced a rethinking of the way water is managed [18]. Most specifically, in the case of Forest, the drivers came from, water policies, such as the European Water Framework Directive (WFD), governance conditions, for example the conflict between top-down traditional practices of water management and bottom-up initiatives organized by neighborhood committees, and, finally, in terms of water hazards, waterways pollution and pluvial flooding.

The second step, the mapping of the context takes into account three types of drivers. We investigate the way in which each driver influenced the governance mechanisms put in place in Forest with an emphasis on the complexity of the actors' structure. Firstly, the investigation of water policies shows the hierarchical structure behind their application and the organization behind their adoption and implementation. This investigation reveals a stronger connection between the European Commission 
objectives and local initiatives with a rupture from the federal and regional governments. Secondly, we aim to regroup the two drivers coming from governance structures and water hazards with an emphasis on the tension between different organizations and between the water cycle and the measures implemented.

Until now, the framework was only applied at a city scale [12], the focus of the current paper on a local council demands changes in the third step, the evaluation methods. We evaluate the governance arrangements, the linkage between different actors and we analyze each type of measure implemented by two of the main actors working with water issues in Forest, Forest Water Department and EGEB association.

In the Australian cases, researchers $[12,17,19]$ used to evaluate the governance arrangements based on the level of centralization of the governance arrangements using two dichotomies: centralized / decentralized and formal / informal. This evaluation allowed positioning the governance structure at a specific level of transition towards SUWM practices. For the case of Forest, we chose to evaluate the governance arrangements in terms of the relationship between different actors based on the classification of Berkes, on cross-scale institutional linkages [20]. This classification allowed connecting actors acting across different scales and also from several levels of organization.

For the second step of the evaluation, we selected a series of criteria that could evaluate the measures from a governance, social and environmental point of view. This wider investigation of the measures proposed or implemented by the two actors shows the diversity of measures possible with the same purpose, a more sustainable mean to manage water in the city. The criteria selected are based on different dichotomies. Firstly, the measures are evaluated by their level of centralization in terms of water systems: centralized/decentralized and formal/informal. While decentralized measures are autonomous entities acting in the same direction, centralized measures act as a whole and are dependent one of each other [21]. The formal/informal couple refers to a network put in place in order for the measure to be implemented and it varies from a hierarchical organization to an ad-hoc creative network [22]. Secondly, considering the long history of public involvement and associative building in BCR, we based our second criterion on a different dichotomy: no participation // remunerated // non - remunerated [23-25]. This criterion highlights the role of a third actor, the neighborhood committees and its relation with the local organizations. The third criterion is based on the work of Rijsberman and Ven on two couples: people or environment oriented and based on values or norms [26]. The couples are not dichotomous and are based on the key elements of sustainable development: the needs of the present generation, the needs of future generations, the carrying capacity of supporting systems and maintaining the ecological, the environmental and hydrological integrity. A mixt of the four elements is desired for a more suitable sustainable response to local problems and by combing two by two, different approaches arose: Carrying capacity, Ratiocentric, Sociocentric, and Ecocentric.

In order to gather a diverse range of information to complete the framework, this paper is based on primary and secondary data collection from different sources. We gathered primary data through interviews or group interviews, attendance to conferences and participation to local assemblies during the period between April 2013 and February 2015. The collection of secondary data is based on several sources coming from academia, documents, publications and media materials on the subject of European water policies, governance mechanisms and sustainable practices. 
In terms of primary data, firstly, the interviews and group interviews were carried with actors actively involved in the decision making process of each organization. The interviewers were identified through recommendation or through attendance at the same meetings. The background of the interviewers was diverse, coming from water operators, regional agencies, academia, private sector, non-profit organizations and community. A first series of interviews (April 2013 - September 2014) was carried based on a semi-structured questionnaire and was meant to capture the actor's role and vision on the current situation of Brussels' water management. The second series of interviews (January - February 2015) were semi-structured, but with the specific objective of identifying the measures adopted by the main organizations implementing SUWM practice in Forest: Forest Water Department, and the nonprofit organization, EGEB. Secondly, we gathered primary data by participating in a series of conferences (April 2013 - February 2015) organized by non-profit organizations in BCR, the European Union Parliament and universities related to innovation in water management, most specifically the ones related to stormwater management. Actors coming from the private sector, local administration, private operators and academia presented the conferences. The attendance to the conferences helped us to have a wider understanding of the current situation in BCR, future projects and possible innovations. Thirdly, we were actively involved in local assemblies (January 2014 - February 2015) with the local administration, non-profit organizations and urban practitioners. The meetings were carried in the context of participatory governance mechanisms, such as Contrat de Quartier, Quartier Durable and design student workshops.

One of the main sources for secondary data collection for water policies were the regulatory plans and documents coming from the European Commission, Brussels' Regional Government, Brussels Environment Regional agency and Forest Local Council. While at the European and Regional level, the information was easier to find in the media, at the local level the regulatory plans were collected directly from the local Water Department. A large series of organizational publications and records together with media materials were consulted in order to understand the structure of each organization and its role in the BCR sector. An important secondary source for elaborating the conceptual framework of analysis came from academic literature on the subject of governance mechanisms and transitional management. The documentation was gathered through desktop research and particular documents from organizations.

\section{Results and Discussion}

\subsection{The present water policies}

Influenced by the Earth summits (1992 Rio de Janeiro, 1995 New York, 2002 Johannesburg), the European Water Framework Directive (WFD) came into force in October 2000 and put pressure on the Member States to start the transition towards SUWM practices [27,28]. Belgium, as member of the European Union since 1958 [29], had to comply with the obligations emitted by the WFD. The directive influenced the development of water policies in BCR and its local councils. Among them, the commune of Forest succeeded in adapting faster to the requirements of the WFD by integrating water policies in urban planning regulations.

WFD influenced the development of water policies in the Member States, by forcing them to release a River Basin Management Plan (RBMP) by 2012 [29,30]. Belgium failed to respect the deadline and 
faced legal action. The difficulties in complying with the timeframe reflected some of the barriers behind the implementation of SUWM in Belgium. The difficulties were at the level of coordination between Belgium's regions [29], in applying WFD to local conditions and the replacement of WFD goals with political concerns leaving as secondary the understanding of the reality of local ecosystems [31].

In 2006, based on the WFD [32], BCR government agreed on delivering a regional RBMP, an integrated part of the RBMP for the Schelde river basin. The BCR's program of measures for the RBMP (Plan Gestion de l'eau) [33] is composed by 8 measures with just one of them specific to BCR's territory, on flood protection [34]. A series of criticisms were directed to the program due to its lack of precisions on the timeframe or the organizations in charge of implementing the measures, lack of tools or criteria to present a cause and effect relation or a methodology for evaluating the effectiveness of this measures [27-29].

The RBMP for BCR was developed under the coordination of Brussels Environmental Agency (BE), a regional administrative body and the participation of regional water operators (VIVAQUA, HYDROBRU, Port de Bruxelles and SBGE). The structure of the stakeholders influencing the water sector in BCR (Figure 2) is based on a high dissemination of roles and tasks difficult to control and coordinate. Just in 2014, BE was recognized as coordinator in organizing watershed committees [35] composed by the regional water operators. Unfortunately, the role of local councils and associations was not mentioned in the new legislation.

At the beginning of 2015, the RBMP for BCR had few effects on urban plans and regulations and are usually just consultative. Even if the plans are available for consultation via online motors or printed copies, there is a lack of understanding of their impact area. During the interviews we carried with practitioners in the urban planning sector, we found that there is a lack of understanding of the reasons and the source of the regulations. The RRU (Regional urban regulation) and the RCU (Communal urban regulation) are the only mandatory urban regulations, which integrate water related measures for new constructions or large renovations. There is a subordinate relation between them, the RCU cannot disagree with the RRU, but has the liberty to propose a higher restriction in a given direction [36]. Each local council has the liberty to elaborate the RCU, but is restricted to the approval of the Regional Government.

In the RRU, there are mandatory regulations relative to stormwater management that are meant to follow the RBMP in terms of water infiltration: green roofs are obligatory for buildings with a surface higher than $100 \mathrm{~m} 2$ of flat roof, water tanks of $331 / \mathrm{m} 2$ of roof surface projective to the horizontal surface and the maintenance of $50 \%$ of permeable surface of unbuilt surfaces [29]. Even if the restrictions are very specific, there are no explanations on the reasons behind the choice of criteria.

A first plan of protection against flooding delivered by Forest local council came into force in 2012 and a new RCU has been adopted at the beginning of 2015 [37]. The RCU in Forest follows the obligations given by the RRU with a more detailed explanation relative to infiltration methods and also the method of detention of stormwater before entering the sewer system. For existing buildings, the commune of Forest decided to enlarge the regulation also to a specific type of restauration [38]. The RCU for Forest is one of the most complete in BCR in relation to the management of stormwater and the protection against flooding, closely connected to the 5th measure of the RBMP or BCR and the Plan Pluie developed by the BCR. 
Figure 2. (a) Actors influencing the water sector in Brussels Capital Region.

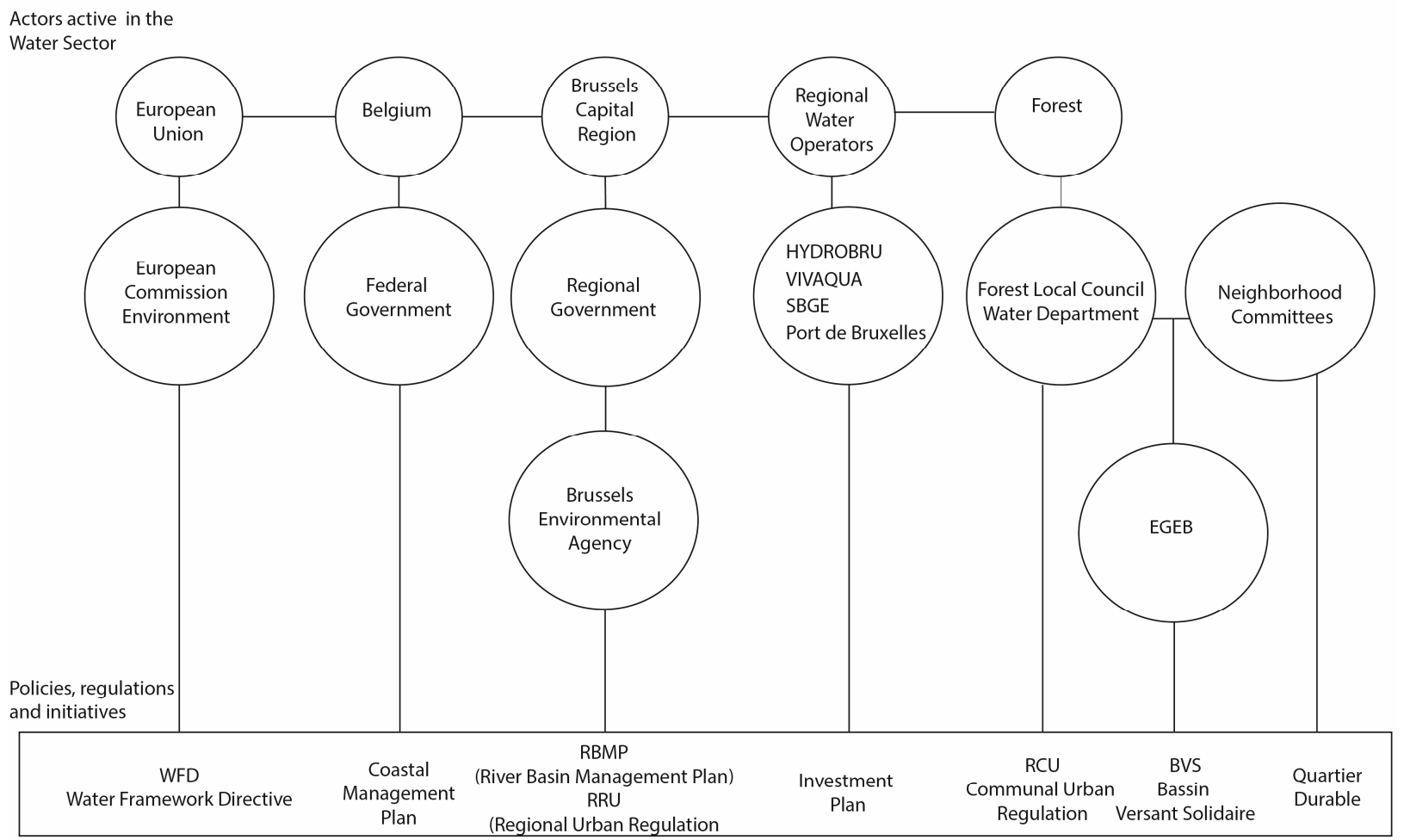

\subsection{The socio-technical systems of the context}

The present Brussels' water system is the result of a strong engineering process started in the second half of the XIX century when the urbanization process knew a significant progress. Historians [39-42] have explained that increased hygiene standards, the need for land on which to build, and the technological progress have been among the main drivers. The use of local resources (water springs and surface water) and the limited onsite use of excrements [42], has been replaced by centralized systems of supply and drainage depending on areas external to the region. Brussels' water system consists, for supply, of an extended drinking water pipe network with related points of abstraction and centralized reservoirs, and, for drainage, of a combined sewerage and stormwater pipe network with centralized peak storage reservoirs and two centralized wastewater treatment plants.

This compartmentalized water system reflects its governance structures. Water is an affair of few institutions whose perspective is most of the time very technical and based on economic figures. Surface water is in the hands of IBGE/BIM (Brussels Environment, the regional agency for the environment) responsible for the streams, the lakes as well as the canal, the Port of Brussels also responsible of the water of the navigable canal crossing the heart of Brussels. SBGE/BMWB (Sociéte Bruxelloise de Gestion de l'Eau) and, in some limited parts, HYDROBRU (Intercommunale Bruxelloise de Distribution et d'Assainissement d'Eau) control the main drainage pipe collectors that have replaced the original streams and rivers. They also monitor the peak storage reservoirs. In addition, SBGE/BMWB controls the South treatment plant. VIVAQUA directly manages the combined sewage network and, on behalf of SBGE/BMWB, the South treatment plant. AQUIRIS, a branch of the international group VEOLIA, has the control of the North treatment plant. Drinking water is governed by HYDROBRU which guarantees 
the distribution as well the communication with the consumers and the system of invoicing, and VIVAQUA which is responsible for the protection of the sources, abstraction, treatment and distribution. The compartmentalization of the water system results in little communication and integration.

Recurrent flood events jeopardize the livability of BCR [43]. The considerable surface paving that occurred in the last decades together with the limited capacity of the combined sewage system are among the main causes. Between the 1950's and the 2000's, in the metropolitan area of Brussels, impervious surfaces on average doubled [44]. This has abruptly increased the stress on the infrastructures engineered to perform drainage. So far, the combined sewage system collecting at once stormwater and wastewater proves do not have enough capacity to deliver downstream the enormous volumes of stormwater runoff linked to major storm events. Overflow of untreated effluents is frequent with serious damages for inhabitants and the overall environment [41]. A considerable amount of the regional rainwater is treated in the two treatment plants, producing a significant loss of energy. If large amounts of rainwater are wasted, in order to supply Brussels, large amounts of water are withdrawn from resources of upstream areas located outside the regional borders. This paradoxical situation becomes more noteworthy if the price of drinking water is regarded. Brussels' drinking water is among the most expensive ones in Europe and its cost expected to increase [45]. The expected changing precipitation and evaporation patterns make the situation worse and raise pressures on the institutions in charge. According to the existing climate models for the central Belgium, a shift of the potential evaporation rates is expected, potentially leading to drier conditions, especially during summer [46]. More uncertainty is linked to the precipitation figures since models forecast sometimes conflicting results [46]. However, what seems clear is that, in the near future, the region will have to cope with a greater uncertainty.

Despite all these problems in the region, the process of change still seems to find little room in the mind-set and programs of the institutions responsible for water. Besides the recently expressed interest to re-arrange the public space in order to perform a more integrated management of water [47], the main stream remains the consolidation of the present technocratic system. Renovation of the outdated pipe networks and the construction of new underground peak storage systems is the sort of projects planned for the coming decades [48].

\subsection{The emergence of a new governance structure}

The complex structure of the relations between different stakeholders in the BCR's water sector, the numerous hierarchical levels of decision making, a higher division of responsibilities among regional or local departments (see Figure 1) together with the multitude of problems due to BCR's traditional water system created the conditions for the emergence of new actors in SUWM practices. In the case of Forest, two actors increased their influence on raising awareness, education and capacity building in implementing SUWM practices. One is Forest Water Department (WD), part of Forest local council and the other is Etats Généraux de l'Eau à Bruxelles (the General water states of Brussels - EGEB), a highly active association in increasing awareness on the benefits of SUWM practices in BCR. In the current paper, we argue that the collaboration between the two actors is one of the reasons behind the fast development of SUWM practices in the commune of Forest. None of this could have been possible without the strong implication and perseverance of a third actor, Forest's neighborhood committees with the main objective being the protection against flooding [49]. 
The interviews carried with the representatives of the two organizations, the participation to presentation conferences and meetings allowed us to compose a detailed understanding of their practices. Further on, we will investigate the main initiatives started by Forest WD and EGEB association in the field of SUWM in Forest with an emphasis on the process and the actors involved.

At the beginning of the 1990's, the management of the sewer system is no longer assured by the local councils, but by an inter-communal agency, Intercommunale Bruxelloise de Distribution d'Eau (since 2006 referred to as Hydrobru). As the drainage system is part of the sewer, HYDROBRU took the lead in protection against flooding by building a series of underground retention basins. Even so, in the present, it is the local council who is responsible for the protection against flooding at the communal level, especially for household floods.

Due to the constant increase in the number of household floods and the constant pressure coming from neighborhood committees, Forest's local council decided to create a Water Department (WD) to analyze the situation. Forest WD is composed by a civil engineer and an environmentalist. This collaboration enabled a larger understanding of the situation and a higher interest on the causes of flooding. Based on the local conditions, Forest WD seized different opportunities of implementing SUWM practices on the territory of Forest that could substitute the end of pipe solutions, such as the ones proposed by Hydrobru.

Forest WD succeeded to get closer to the neighborhood committees and to create a real exchange of knowledge on the question of water. This exchange had as objective the investigation of the local situation and the main causes of flooding. The investigation was made by volunteer citizens and followed the history of the area and the way the commune changed its hydrographic structure, the gathering of real-time data on the effects of flooding in private and public areas of the commune and on the effects of the urbanization and water usage on the increase in flooding.

This wider understanding of the local conditions encouraged Forest WD to implement a series of structural and non-structural measures, which together started a more diversified action towards SUWD practices and an increase in livability.

As structural measures, a series of on-ground works were implemented. Firstly, the project in Jaques Brel Park was a first example of the success of the negotiations carried by Forest WD. The main challenge of this project was to convince the companies with headquarters at the limit of the park to build a new sewer system in order to improve the water quality of two lakes. Secondly, the council agreed on the construction of two underground retention basins realized by Vivaqua [50]. The projects aimed to prevent flooding caused by the overflow of the sewer system. Thirdly, a series of on-going ground works are coordinated by Forest WD in order to use the existing water sources and the stormwater to recreate a network of new urban rivers. This project is still at the level of discussion due to difficulties in managing different street functions, such as traffic, parking or energy and gas distribution.

In terms of non-structural measures, firstly, Forest WD focused on integrating water related policies in urban planning regulations. A new RCU was released in March 2015 and introduced more specific demands for infiltration and detention measures [38]. Secondly, Forest WD, through regional programs, took the opportunity to introduce incentives for the rehabilitation of rainwater tanks. Thirdly, a series of initiatives were developed in order to raise awareness among the inhabitants about water related problems. 
The specific collaboration of Forest WD with EGEB association and the neighborhood committees allowed a faster dissemination of knowledge and the integration of water issues in urban planning regulations. The biggest challenges encountered by the department came from other departments within the Forest local council. The pressure on urban space in Forest is important and the challenge is to find a mean to create multifunctional landscape that could mitigate this pressure.

EGEB association is renowned in Brussels for their capacity to activate citizens' participation in water related issues. The association paved the way towards the implementation of a new concept: "Bassin Versant Solidaire" (BVS) (catchment solidarity) in BCR. The concept is strongly related to one of the main demands of the European WFD, managing water at the level of the catchment. The members of the association do not relate to the WFD or mention its influence, but consider the start of the concept of BVS as a reaction to the social realties in BCR's valleys. The disparity between the inhabitants leaving uphill and downhill in the valley is strongly visible in terms of income, public space and household values [51]. More than that, the areas at the bottom of the valley are considered to be one of the most sensitive to pluvial flooding [52]. Based on these observations, EGEB association finds important in the transition to SUWM practices, to introduce the BVS concept to enable a link between the uphill and downhill not just for the water cycle, but also for social cohesion.

In 2015, EGEB association is actively working on three pilot projects: the Maellbeek Valley, the Molenbeek Valley and the Forest council, part of the Zenne Valley. Among the three, the action in Forest developed faster and moved from raising awareness among the community towards a closer collaboration with the administration in delivering practical measures.

The first action of EGEB association was located in the Maelbeek valley and became the driver for future pilot projects. The goal was to guide the community in opposing the authorities' decision to build an underground stormwater retention basin underneath a central public space in BCR, Place Flagey. They seized the moment as an opportunity to enable a change in water management and more than that in the way urban planning decisions were taken in BCR. In the end, the underground stormwater retention basin was built and the square was transformed into a large sealed open public space. Even if the opposition did not succeed to change the authorities' decision, it showed the impressive awareness and understanding of what kind of SUWM practices could be integrated in the dense environment of BCR. The action in the Maelbeek valley continued with a series of guided tours, community workshops and information brochures, which raised awareness among the community on the biodiversity of the valley and the damaging effects of urbanization.

The initiatives in the Molenbeek valley began in the summer of 2014 with the start of a series of guided visits. The valley is one of the poorest in the BCR so the challenges in this case are passing over the water issues to social cohesion and the resistance to gentrification. In this case, results are waiting to appear.

The action in Forest lead by EGEB association started with guiding the inhabitants in one of the participatory regional programs: quartiers durables. The neighborhood which enabled the action is found on the upper side of Forest and was not motivated by water issues, but by the decision of Forest local council to cut most of the street trees. The neighborhood committee strongly opposed the decision and seized the opportunity to go even further and to integrate water related issues. In 2015, the project proposal is developed by a landscape office and was well received by the community and Forest WD, but it did not received yet funding for the physical realization. 
EGEB association organized a series of workshops in Forest with the objective to map the current situation. The mapping tool used, Map-it was developed by researchers from Ghent University and adapted by a local architectural office. The three session of Map-it succeed to identify the problems related to water in Forest and to arrive at several objectives and visions for the future development. The sessions were not only a success in terms of developing future scenarios for the commune, but it brought together inhabitants from different social, cultural or economic background living uphill or downhill. The results of the Map-it were presented during a round table discussion, which hosted representatives of the local and regional administration, water operators, private sector, academia and inhabitants. The round table was considered a success and a first step towards a Bassin versant solidaire.

According to EGEB association, the Round Table lead to the entering in force of a new regional law in August 2014 mandating the organization of working groups based on each BCR's valley [35]. The coordinator will be Brussels Environmental Agency and the members will be the regional administration and the water operators. Unfortunately, there is no specification made on the role of local administrations, inhabitants or non-profit associations. The law is also a result of the BCR water directive and the European WFD.

EGEB association became trustworthy from the point of view of the local council and the neighborhood committees as consultative body on any water related problem. The actors are starting to multiply and the EGEB are in competition with different other associations. With an achieved informal legitimacy, the EGEB is lacking a formal and financial recognition. There is an important moment of passing from a spontaneous bottom-up initiative to a formal way of action. EGEB is starting to exit the experimental phase and needs a more structural type of activity in order to achieve its objectives. For now, the association is involved in new regional programs in collaboration with different associations, practitioners and academia for receiving funding for their initiatives.

It is important to mention, that all the initiatives coordinated by Forest WD or EGEB association are in a large part initiated or sustained by the neighborhood committees, a bottom-up initiative born from the lack of support from the municipality to protect the households from flooding. This third actor has a formal influence on the urban planning decisions in Forest through three types of participatory means put in place by BCR or the Local Council, Quartier Durable (Sustainable neighborhood), Contrat de Quartier (Neighborhood contract) and Public reviews of large urban projects. These means only partially finance the program excluding the physical realization, they often lack transparency in the way projects are selected and financed or their criticisms are not all the time taken into consideration. Thus, these means proved to be insufficient for the neighborhood committees' goal to improve the commune's livability and to protect it from water related hazards.

According to the interviews we carried out, the neighborhood committees are an active actor and use informal methods to influence the local administration. Their influence created the link between Forest WD and EGEB association. The relation between Forest WD, EGEB association and the committees created conditions for a new type of active participation. Most of the initiatives of Forest WD or EGEB association were suitable to the context as part of this collaboration due to a deep understanding of the local conditions. 


\section{Experimental Section}

\subsection{The Governance structure in Forest}

The governance structure in the case of Forest for implementing SUWM practices is composed by four main actors. Each actor is connected with another one by different type of linkages. The network is not homogenous or uniform, but this is actually a quality, it allows it to be more flexible (Figure 3). All the measures initiated by Forest WD (Table 1) and EGEB association (Table 2) took advantage of the complexity of the network and sized opportunities in the way the Regional Government manages the issue of water. The neighborhood committees have a central role in enabling change and bringing the local knowledge in the implementation of each measure.

Table 1. Measures initiated by the Water Department of Forest

\begin{tabular}{|c|c|c|c|c|}
\hline Measures & $\begin{array}{l}\text { Structural / } \\
\text { Non-Structural }\end{array}$ & Timeframe & Status & Collaboration Partners \\
\hline Park Jaques Brel (finalized) & Structural & $2012-2013$ & Completed & $\begin{array}{l}\text { Uccle local Council, Jaques } \\
\text { Brel companies, Vivaqua }\end{array}$ \\
\hline Bempt Avenue (on-going) & Structural & 2013 - future & Plan & $\begin{array}{l}\text { Forest Urban Planning } \\
\text { Department }\end{array}$ \\
\hline New Urban Rivers initiative & Structural & 2013-Future & Vision & $\begin{array}{l}\text { Neighborhood committees, } \\
\text { EGEB }\end{array}$ \\
\hline $\begin{array}{l}\text { Stormwater retention basin (Audi and } \\
\text { Baeck) }\end{array}$ & Structural & $2006-2014$ & Completed & Vivaqua \\
\hline $\begin{array}{l}\mathrm{RCU}-\text { stormwater management } \\
\text { released and adaptation }\end{array}$ & Non-Structural & 2009-2015 & Released & BCR Regional government \\
\hline $\begin{array}{l}\text { Coordination working group with } \\
\text { regional water operators }\end{array}$ & Non-Structural & 2010 - present & $\begin{array}{l}\text { On-going } \\
\text { initiative }\end{array}$ & $\begin{array}{l}\text { Bruxelles environnement, } \\
\text { Vivaqua, Hydrobru, SBGE }\end{array}$ \\
\hline Organization Water Day & Non-Structural & 2012 & $\begin{array}{l}\text { On-going } \\
\text { initiative }\end{array}$ & EGEB \\
\hline $\begin{array}{l}\text { Plan Communal de Lutte contre les } \\
\text { Inondations (Communal flood } \\
\text { management plan) }\end{array}$ & Non-Structural & 2012 & Released & BCR \\
\hline $\begin{array}{l}\text { Household incentives for restoring } \\
\text { rainwater tanks }\end{array}$ & Non-Structural & $2015-2018$ & $\begin{array}{l}\text { On } \\
\text { discussion }\end{array}$ & $\begin{array}{l}\text { Contrat Quartier Abbey, } \\
\text { Vivaqua }\end{array}$ \\
\hline
\end{tabular}

The approach of Forest WD in implementing SUWM practices can be considered of the bottom-up type in relation to the European Commission and the Regional Government, but it has a top-down position in the way initiatives are implemented. A lack of specifications regarding water management practices in the urban planning regulation at the regional level allowed the development of a comanagement relation between the Regional Government and Forest local council in relation to water practices. Under these conditions, Forest local council had the opportunity to incorporate in their urban 
regulations stronger water related interdictions and obligations in relation to infiltration and detention of stormwater.

In the case of the relation between EGEB association and the Regional Government, researchers (Berkes, 2006) refer to this type of governance arrangement as "citizens' science". This arrangement is usually developed in industrial countries with a strong associative tradition, as it is in the case of BCR. The knowledge "citizens' science" comes from a mix of scientific evidence and observation on site. Similar to the case of EGEB association, the relation with the Regional government is usually in terms of sharing information and policy partnership, but it is not a real sharing of power and a formal recognition of the role of EGEB association in water related issues.

The governance arrangement between the local government and EGEB association tends to borrow some strategies from the "citizens science" and co-management practices. There is an informal recognition of Forest WD regarding the role of EGEB association and the sharing of power is made just in terms of participatory processes. We can refer to as Development, Empowerment, Co-Management Arrangements [20] with a low sharing of power between three actors: Forest Water Department, EGEB association and the neighborhood committees.

Table 2. Measures initiated by EGEB association.

\begin{tabular}{|c|c|c|c|c|}
\hline Measures & $\begin{array}{l}\text { Structural / } \\
\text { Non- } \\
\text { Structural }\end{array}$ & Timeframe & Status & Collaboration Partners \\
\hline $\begin{array}{l}\text { Three Map - it sessions for mapping the context, } \\
\text { the inhabitants' aspirations and future objective } \\
\text { for a sustainable water management in Forest }\end{array}$ & Structural & $2013-2014$ & Completed & Neighborhood \\
\hline Blue-green guided tours & Non-Structural & 2013 - Present & On-going & $\begin{array}{l}\text { Forest } \\
\text { committees }\end{array}$ \\
\hline $\begin{array}{l}\text { Introducing the concept of 'Bassin versant } \\
\text { solidaire' (Catchment solidarity) }\end{array}$ & Non-Structural & 2013 - Present & On-going & $\begin{array}{l}\text { Forest } \\
\text { committees }\end{array}$ \\
\hline $\begin{array}{l}\text { Organization of a round table on the topic of } \\
\text { Catchment solidarity regrouping regional and } \\
\text { local administration, water operators, } \\
\text { researchers, associations and neighborhood } \\
\text { committees }\end{array}$ & Non-Structural & $2010-2015$ & Released & $\begin{array}{ll}\text { Forest } & \text { Neighborhood } \\
\text { committees, } & \text { Forest Local } \\
\text { Council } & \end{array}$ \\
\hline Coordination of student design workshops & Non-Structural & 2012 & $\begin{array}{l}\text { On-going } \\
\text { initiative }\end{array}$ & $\begin{array}{l}\text { Researchers, Faculty of } \\
\text { Architecture (ULB) }\end{array}$ \\
\hline $\begin{array}{l}\text { Assisting the inhabitants in the Contrat de } \\
\text { Quartier Abbey and the Quartier Durable } \\
\text { Neptune }\end{array}$ & Non-Structural & $2012-2018$ & $\begin{array}{l}\text { On-going } \\
\text { initiative }\end{array}$ & $\begin{array}{l}\text { Researchers, Faculty of } \\
\text { Architecture (ULB), Urban } \\
\text { design and planning offices }\end{array}$ \\
\hline
\end{tabular}

The governance structure in Forest diversified over a period of 5 years, 2010-2015, with the establishment of Forest WD and the connection established with the EGEB association and the neighborhood committees. The challenges of the current structure is to make a transition towards the 
stabilization of roles and the integration of other actors from the water sector, such as Brussels Environmental Agency and the water operators. The current governance structure allows the diversification of roles and capacities. Traditionally, the regional government had a top-down approach in working with the local council, association and neighborhood committees. The creation of a more diversified relation among the bottom-up actors allowed to change the balance and to enable the diversification of governance arrangements.

Figure 3. (a) Governance structure in Forest for creating the conditions to enable the transition towards SUWM practices.

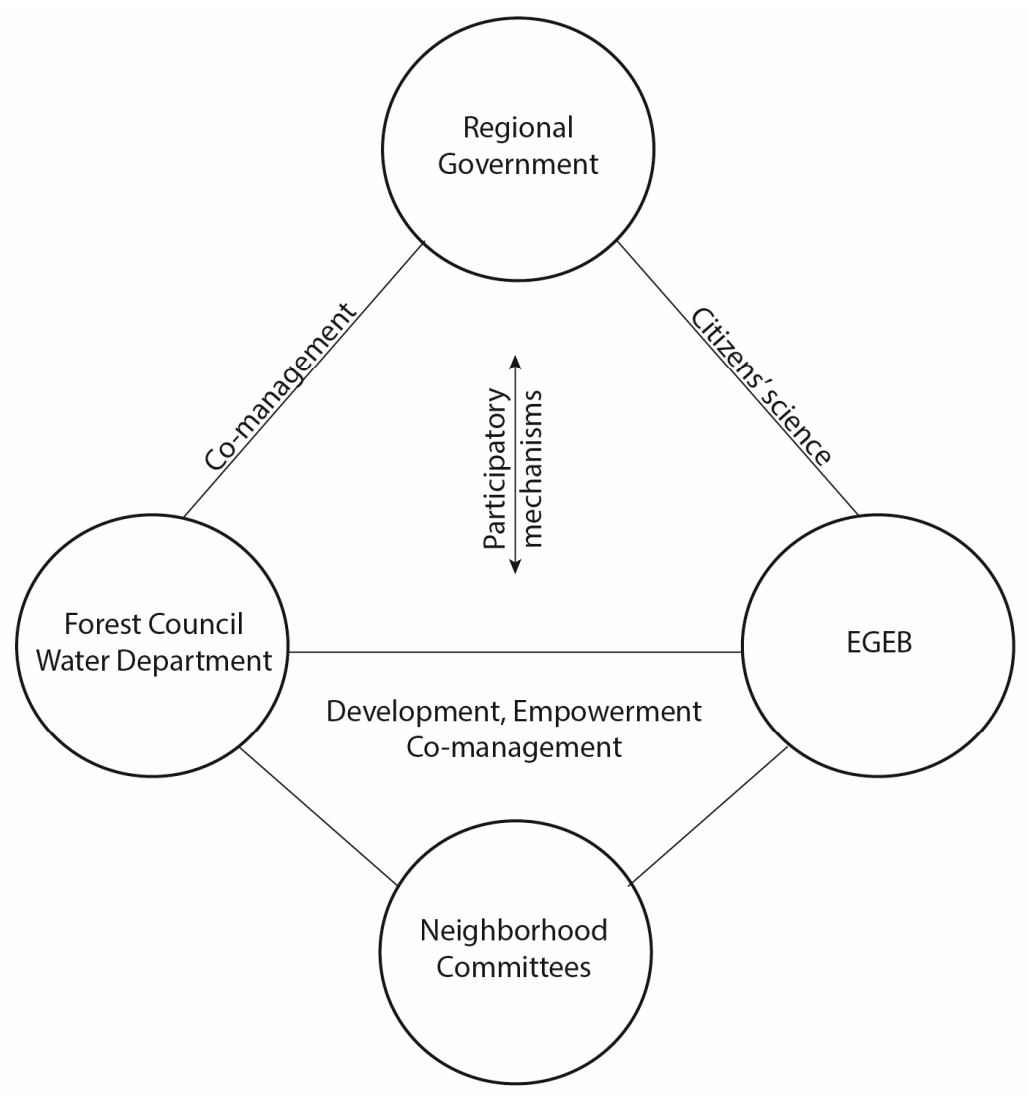

\subsection{Evaluation of measures implemented by Forest WD and EGEB association}

In this section we evaluate the measures initiated by the Water Department and EGEB association in water management (Table 3) that were enabled by the governance structure previously analyzed. The evaluation is made based on the three series of criteria, explained in the first section of the current paper: level of centralization, the driver of the measure with the type of approach and the level of participation of the inhabitants. This evaluation allows us to have a deeper overview of each type of measure and their capacity to enable a transition towards SUWM practices.

The first criterion was used by researchers in the analysis of the Australian case studies [12] and was based on centralized / decentralized and formal / informal criterion. In the case of Forest, there is a clear tendency of Forest WD to introduce decentralized measures in terms of water policies. For on-ground works, Forest WD supports a combined use of centralized and decentralized measures in order to have a diversification of means to protect against flooding. The measures of EGEB association, due to the 
nature of the association, are decentralized and informal. The organization of formal round tables reveals the tendency of the association to move into a new phase, in the search of a more formal legitimacy of action.

Related to the second criterion, researchers agreed [26] on the fact that SUWM practices lead to various benefits, if they are the result of the integration of different approaches to the environment. Within the measures initiated by Forest WD and EGEB association, we can find a mixture of the four approaches Carrying Capacity, Ecocentric, Rationcentric and Sociocentric. Even so, there is a clear tendency towards Ecocentric and Sociocentric initiatives.

Considering the third criterion, the relation to the inhabitants results stronger in the case of the EGEB association, who is specifically focused on their participation. EGEB association is actually considered a mediator between the Local council and the neighborhood committees and finds it difficult to change their status. The position does not allow them to have a stronger impact at the level of the administration, as an independent consultative body. Forest WD succeeds in maintaining a more balanced relation with the inhabitants and usually this is done via EGEB association.

The measures implemented by Forest WD and EGEB association appear complementary, especially in terms of citizens' participation. After a deeper analysis, by comparing the measures implemented by the two organization and the interviews we carried, we perceived some degree of roles overlapping. On one side Forest WD aims to be more involved in the inhabitants' initiatives and considers EGEB association as an important mediator in this interaction. On the other side, EGEB association grew in expertise on water issues and aims to have a guiding role in the implementation of initiatives, not just as mediator in participatory initiatives. Both organizations are currently in a transition phase and in the stabilization of their roles. The success of their measures was in a big measure due to their way to interact with citizens and succeed to have diverse range of practices. This diversification of practices helps to take a step forward in the transition of SUWM practice, but it can be also unproductive if the actors do not succeed to have a more transparent collaboration with a clear understanding of their roles. Forest local council should take the role of coordination, but fails until now to show its practical involvement.

\section{Conclusions}

Based on the transition framework towards SUWM practices developed on Australian cities [12], the governance structure and arrangements in Forest municipality are situated in the transition stage of Takeoff. This stage is the second in the development towards a stabilization of SUWM practices. A hybrid structure composed by bottom-up and top-down initiatives sustained by new policies and on-going onground works characterize this stage. Similar to this stage, as we previously referred to, the governance structure in the case of Forest municipality passes through a transition from the top-down - bottom-up dichotomy to governance arrangements based on development, empowerment and co-management. We argue that this transition was enabled by the appearance of two bridging actors, Forest WD and EGEB association. After the analysis of the source of each measure implemented by the organizations, a third actor appears as important, but with a lower recognition, the neighborhood committees. 
Table 3. Analysis of the measures initiated by the two organizations (Forest WD and EGEB association).

\begin{tabular}{|c|c|c|c|c|c|c|c|c|}
\hline Organization // Measures & Centralized & Decentralized & Formal & Informal & $\begin{array}{l}\text { People } \\
\text { environment } \\
\text { oriented }\end{array}$ & $\begin{array}{l}\text { Based on } \\
\text { Values / } \\
\text { Norms } \\
\end{array}$ & $\begin{array}{l}\text { Type of } \\
\text { Approach }\end{array}$ & Inhabitants participation \\
\hline \multicolumn{9}{|l|}{ Water Department } \\
\hline $\begin{array}{l}\text { Park Jaques Brel (finalized) // Bempt Avenue } \\
\text { (on-going) }\end{array}$ & & $\mathrm{x}$ & $\mathrm{x}$ & & Environment & Values & Ecocentric & $\begin{array}{l}\text { Remunerated Participation // } \\
\text { Non-Remunerated Participation }\end{array}$ \\
\hline $\begin{array}{l}\text { Stormwater retention basin (Audi and Baeck) } \\
\text { - Vivaqua }\end{array}$ & $\mathrm{x}$ & & $\mathrm{x}$ & & Environment & Norms & $\begin{array}{l}\text { Carrying } \\
\text { Capacity }\end{array}$ & No Participation \\
\hline New Urban Rivers initiative & & $\mathrm{x}$ & $\mathrm{x}$ & $\mathrm{x}$ & Environment & Values & Ecocentric & Non-Remunerated Participation \\
\hline $\mathrm{RCU}$ - stormwater management regulation & & $\mathrm{x}$ & $\mathrm{x}$ & & Environment & Norms & $\begin{array}{l}\text { Carrying } \\
\text { Capacity } \\
\end{array}$ & No Participation \\
\hline Organization Water Day & & $\mathrm{x}$ & $\mathrm{x}$ & $\mathrm{x}$ & People & Values & Sociocentric & Non-Remunerated Participation \\
\hline \multicolumn{9}{|l|}{ EGEB association } \\
\hline $\begin{array}{l}\text { Three Map - it sessions for mapping the } \\
\text { context // Blue-green guided tours }\end{array}$ & & $\mathrm{x}$ & & $\mathrm{x}$ & People & Norms & Ratiocentric & Non-Remunerated Participation \\
\hline $\begin{array}{l}\text { Introducing the concept of 'Bassin versant } \\
\text { solidaire' (Catchment solidarity) }\end{array}$ & & $\mathrm{x}$ & & $\mathrm{x}$ & $\begin{array}{l}\text { Environment / } \\
\text { People }\end{array}$ & Values & Ecocentric & Non-Remunerated Participation \\
\hline $\begin{array}{l}\text { Organization of round tables // Coordination } \\
\text { of student design workshops }\end{array}$ & & $\mathrm{x}$ & $\mathrm{x}$ & & People & Norms & Ratiocentric & Non-Remunerated Participation \\
\hline $\begin{array}{l}\text { Assisting the inhabitants in participatory } \\
\text { mechanisms }\end{array}$ & $\mathrm{x}$ & & $\mathrm{x}$ & & People & Values & Sociocentric & Non-Remunerated Participation \\
\hline
\end{tabular}


There are still two stages in the transition towards SUWM that Forest has to pass through in order to make SUWM a common practice. The summary table (Table 3) shows a small amount of carrying capacities approaches that have the capability to embed this type of practice. Not only should the measures change, but also the actors and the linkages between them. Forest WD will need a stronger connection with the other departments from the Forest Local Council and EGEB association lacks a formal legitimacy in order to continue the activities and to have a stronger impact at the regional level. The neighborhood committees will need also more participatory tools to put in practice their ideas. The change should come also at the level of the Regional Government that will allow the measures started in Forest to be more than local and to enhance collaboration between the municipalities. This role is starting to be foreseen by Brussels Environmental Agency, who has the expertise to implement SUWM practices. Unfortunately, in the present, the agency has a very low capacity in this direction.

The fit-for-purpose framework allowed to isolate the main purpose of changes in the governance structure and to identify the drivers of transitions. Even if, it was applied until now just at the city scale, the framework is adaptable also to the local scale. In the case of Forest, we found it important to enter deeper in the evaluation of the measures due to the lack of recognition of SUWM in BCR. We chose to focus on the Forest municipality and not to the whole BCR due to the low dissemination of SUWM practices. The concentrated number of activities related to SUWM in Forest draw our attention and it proved to be a good starting point in understanding the drivers, which enabled a better dissemination of water, related measures. While at the regional level, BCR government struggles to integrate the European Water Framework directive in implementing SUWM, it is at the local level, in Forest, that the local conditions and the leading actors allowed to by-pass the regional directives and to move faster in this direction.

Forest case study revealed the importance of local conditions and the role of bridging actors in enabling change. Even if, criticism oriented on the applicability of the European WFD lead to problems at the level of Member States, the principles of SUWM were developed in parallel at the local scale, where the inhabitants desired a more livable and safe urban space. While in countries like Australia, UK, Germany or US, technical issues of implementing SUWM were developed in parallel with the study of barriers in transition to a new type of water practices, in BCR there is still a lack of understanding on how to apply them in the local conditions. These technical problems make each project difficult to adopt and demands a large amount of time. The interviews with the professionals and Forest WD showed their interest in searching for examples to other countries and adapting them to the BCR context.

\section{Acknowledgments}

We will like to acknowledge the interesting collaboration with the members of EGEB association, who were always open for discussion and gave us as many details as possible. We will like to express our gratitude towards the Forest Local Council, especially the Water Department for their open-mind and perseverance. In addition, we are giving our thanks to all the persons who were open to provide us information and advices, from Vivaqua, Hyrdobru and Brussels Environmental Agency. We will like to show our appreciation to the inhabitants of Forest, especially for the ones part of the Comite de quartier Stop Innondations, for their constant interest, involvement and perseverance on the question of water. Their valuables contribution helped in developing this paper. 


\section{Conflict of Interest}

The authors declare no conflict of interest.

\section{References and Notes}

1. Dietz, M. E. Low Impact Development Practices: A Review of Current Research and Recommendations for Future Directions. Water. Air. Soil Pollut. 2007, 186, 351-363.

2. Butler, D.; Parkinson, J. Towards sustainable urban drainage. Water Sci. Technol. 1997, 35, 53-63.

3. Chocat, B.; Bertrand-Krajewski, J.-L.; Barraud, S. Eaux pluviales urbaines et rejets urbains par temps de pluie. Tech. l'ingénieur. Technol. l'eau 2007, 2, 19.

4. Bevington, C.; Levin, D.; Robinson, P.; Davis, P.; Abbott, J.; Simkins, P.; Shaffer, P. water sensitive urban design in the UK. Ideas for built environment practitioners; CIRIA: London, 2013.

5. Ashley, R.; Shucksmith, J.; Blanksby, J.; Sharp, L.; Tait, S.; Shaffer, P.; Stam, J.-M. Water sensitive urban design in a European context. In 8th International Water Senitive Urban Design Conference 2013; Gold Cost, Qld., 2013.

6. Fletcher, T. D.; Shuster, W.; Hunt, W. F.; Ashley, R.; Butler, D.; Arthur, S.; Trowsdale, S.; Barraud, S.; Semadeni-Davies, A.; Bertrand-Krajewski, J.-L.; Mikkelsen, P. S.; Rivard, G.; Uhl, M.; Dagenais, D.; Viklander, M. SUDS, LID, BMPs, WSUD and more - The evolution and application of terminology surrounding urban drainage. Urban Water J. 2014, 1-18.

7. Wong, T. H. F. Water Sensitive Urban Design - the Journey Thus Far. Eng. Aust. 2007, 1 10, 213 -222 .

8. Novotny, V.; Novotny, E. V Water Centric Cities of the Future - Towards Macro Scale Assessment of Sustainability. 2011, 1-14.

9. CRC for Water Sensitive Cities Submission to the 2014 Triennial Assessment of water reform progress in Asutralia; Melbourne, 2014.

10. Ward, S.; Woods, A.; Teh, T.-H.; Tahir, S. Challenging traditions - Chasing transitions: water reuse in the UK. In IWA Cities of the Future Conference, Stockholm, Sweden, 23rd - 25th May 2011; Stockholm, 2011.

11. Brown, R. R.; Keath, N.; Wong, T. H. F. Urban water management in cities: historical, current and future regimes. Water Sci. Technol. 2009, 59, 847-55.

12. Rijke, J.; Farrelly, M.; Brown, R.; Zevenbergen, C. Configuring transformative governance to enhance resilient urban water systems. Environ. Sci. Policy 2013, 25, 62-72.

13. Andersson, I.; Petersson, M.; Jarsjö, J. Impact of the European Water Framework Directive on locallevel water management: Case study Oxunda Catchment, Sweden. Land use policy 2012, 29, $73-$ 82.

14. Brown, M.; Libeman, M. Bringing water sensitive design into mainstream; 2004.

15. Folke, C.; Hahn, T.; Olsson, P.; Norberg, J. Adaptive Governance of Social-Ecological Systems. Annu. Rev. Environ. Resour. 2005, 30, 441-473.

16. Rijke, J.; Brown, R.; Zevenbergen, C.; Ashley, R.; Farrelly, M.; Morison, P.; van Herk, S. Fit-forpurpose governance: A framework to make adaptive governance operational. Environ. Sci. Policy 2012, 22, 73-84. 
17. Rijke, J.; Farrelly, M. Creating water sensitive cities in Australia: the strengths and weaknesses of current governance approaches. In WSUD 2012: Water sensitve urban design; Building the water sensitve community; 7th international conference on water sensitive urban design, 21 - 23 February 2012; Melbourne, 2012.

18. Brown, R.; Clarke, J. Transition to water sensitive urban design. The story of Melbourne, Australia.; Melbourne, 2007.

19. Rijke, J. Delivering change. Towards fit-for-purpose governance of adaptation to flooding and drought, TU Delft, 2014.

20. Berkes, F. Cross-scale institutional linkages: Perspectives from the Bottom-up. In The Drama of the commons; Ostrom, E.; Dietz, T.; Dolsak, N.; Stern, P.; Stonich, S.; Weber, E., Eds.; National Academy Press: Washington DC, 2006; pp. 293-321.

21. Mankad, A.; Tapsuwan, S. Review of socio-economic drivers of community acceptance and adoption of decentralised water systems. J. Environ. Manage. 2011, 92, 380-391.

22. Pahl-Wostl, C. Towards sustainability in the water sector - The importance of human actors and processes of social learning. Aquat. Sci. 2002, 64, 394-411.

23. Brown, D. Good Practice Guidelines for Indicator Development and Reporting. In Third World Forum: Statistics, Knowledge and Policy; Busan, Korea, 2009.

24. Brown, R.; Farrelly, M. Barriers to Advancing Sustainable Urban Water Management : a typology. In 13th International Rainwater Catchment Systems Conference "Rainwater and Urban Design 2007”; Barton, A., Ed.; Engineers Australia: Sydney, 2007; pp. 229-236.

25. Unit, E. I.; Siemens, A. G. European Green City Index; Siemens AG 99: Munich, 2009.

26. Rijsberman, M. A.; Ven, F. H. M. Van De Different approaches to assessment of design and management of sustainable urban water systems. 2000, 20, 333-345.

27. Hering, D.; Borja, A.; Carstensen, J.; Carvalho, L.; Elliott, M.; Feld, C. K.; Heiskanen, A. S.; Johnson, R. K.; Moe, J.; Pont, D.; Solheim, A. L.; de Bund, W. Van The European Water Framework Directive at the age of 10: A critical review of the achievements with recommendations for the future. Sci. Total Environ. 2010, 408, 4007-4019.

28. Dworak, T.; Gonzalez, C.; Laaser, C.; Interwies, E. The need for new monitoring tools to implement the WFD. Environ. Sci. Policy 2005, 8, 301-306.

29. European Parliment and the Council of the European Union Report on the Water Framework Directive River Basin Management Plans. Memeber State: Belgium; Brussels, 2015.

30. Kundzewicz, Z. V; Becker, A.; Hattermann, F. F. Introduction. In Water Framework Directive: Model supported implementation a water mnager's guide; Hattermann, F. F.; Kundzewicz, Z., Eds.; Lonond - New York, 2010; pp. 1-11.

31. Moss, B. The Water Framework Directive: Total environment or political compromise? Sci. Total Environ. 2008, 400, 32-41.

32. Brussels Capital Region Ordonance Cadre Eau Octobre 2006; Brussels Capital Region: Belgium, 2006.

33. Brussels Capital Region (BCR) Plan de gestion de l'eau - Questions importantes; Brussels, 2009; pp. 1-19.

34. Maufroy, L. (Agence de developpment territorial) Plan régional de développement durable. Etude des lieux de la Région Bruxelles Capitale; Brussels, 2011. 
35. Brussels Capital Region (BCR) Arrêté du Gouvernement de la Région de Bruxelles-Capitale coordonnant les missions de service public des opérateurs et acteurs dans la mise en oeuvre de la politique de l'eau et instaurant un comité des usagers de l'eau; Brussels Capital Region, 2014.

36. IBGE-BIM Plan de gestion de l'eau (River basin mangament plan RBMP) $\mathrm{http}: / / \mathrm{www}$.environnement.brussels/thematiques/eau/plan-de-gestion-de-leau (accessed Apr 14, 2015).

37. Mannes, E.; Da Cruz, M. Vers une politique intégrée et participative de la gestion des eaux pluviales. L'exemple forestois 2015.

38. Forest Local Council Reglement communal d'urbanisme en matiere de gestion des eaux pluviale; Forest Local Council: Belgium, 2015.

39. Deligne, C. Bruxelles sortie des eaux: les relations entre la ville et ses cours d'eau du moyen âge à nos jours (Brussels out of the water: the relationship between the city and its waterways from the Middle Ages to the present day); 7th ed.; Musées de la Ville de Bruxelles.: Brussels, 2005; p. 63.

40. Deligne, C. The rivers of Brussels, 1770-1880: transformations of an urban landscape. In Urban rivers: remaking rivers, cities, and space in Europe and North America; Castonguay, S.; Evenden, M., Eds.; University of Pittsburgh Press: Pittsburgh, 2012; pp. 17-33.

41. IBGE-BIM "RIE du projet de programme de mesures PGE". Rapport sur les incidences environnementales du projet de programme de mesures accompagnant le plan de gestion de l'eau de la Région de Bruxelles-Capitale ("RIE programme measures proposal PGE)." Report on the. In Plan de gestion de l'eau (Water management plan); Brussels, 2011.

42. Kohlbrenner, A. De l'engrais au déchet, des campagnes à la rivière : une histoire de Bruxelles et de ses excréments (Fertilizer to waste, campaigns to the river: a history of Brussels and its excrement). Brussels Stud. 2014, 78.

43. De Bondt, K.; Claeys, P. Flooding risk in Brussels, water retention capacity of geological units. In We can change the weather, 100 cases of changeability; Wynants, M., Ed.; VUB Press: Brussels, 2010.

44. Vanhuysse, S.; Depireux, J.; Wolff, E. Etude de l'évolution de l'imperméabilisation du sol en Région de Bruxelles-Capitale (Study of the evolution of soil sealing in the Brussels-Capital Region).; Brussels, 2006.

45. Hydrobru Tarifs ordinaires de fourniture d'eau et d'assainissement (Standard rates of water supply and sanitation). http://www.hydrobru.be/nos-tarifs/tarifs-ordinaires-de-fourniture-etdassainissement/ (accessed Apr 24, 2015).

46. Baguis, P.; Roulin, E.; Willems, P.; Ntegeka, V. Climate change scenarios for precipitation and potential evapotranspiration over central Belgium. Theor. Appl. Climatol. 2009, 99, 273-286.

47. IBGE-BIM Guide bâtiment durable (Sustainable building guide).; Brussels, 2014.

48. Pyren, O. Personal communication 2014.

49. Comite de quartier Stop Innondations Comite de quartier Stop Innondations Saint-Denis (Neighborhood committee Stop Flooding Saint-Denis) https://stopinondations.wordpress.com/2012/05/21/inondations-du-20-mai-2012/\#comments (accessed Apr 14, 2015).

50. VIVAQUA Rapport d'activites 2013; Brussels, 2014. 
51. Brussels Capital Region - BCR Monitoring des quartiers https://monitoringdesquartiers.irisnet.be (accessed Apr 24, 2015).

52. IBGE-BIM Alea et risque d'innondation (Hazard and flooding risk) http://geoportal.ibgebim.be/webmap/inondation_carte.phtml (accessed Apr 20, 2015).

(C) 2015 by the authors; licensee MDPI and IFoU, This article is an open access article distributed under the terms and conditions of the Creative Commons Attribution license. 